\title{
Discovery and Characterization of Xylella fastidiosa Strains in Southern California Causing Mulberry Leaf Scorch
}

\author{
R. Hernandez-Martinez, Department of Plant Pathology, University of California, Riverside 92521; T. R. Pinckard \\ and H. S. Costa, Department of Entomology, University of California, Riverside 92521; and D. A. Cooksey and \\ F. P. Wong, Department of Plant Pathology, University of California, Riverside 92521
}

\begin{abstract}
Hernandez-Martinez, R., Pinckard, T. R., Costa, H. S., Cooksey, D. A., and Wong, F. P. 2006. Discovery and characterization of Xylella fastidiosa strains in southern California causing mulberry leaf scorch. Plant Dis. 90:1143-1149.

Mulberry leaf scorch (MLS), caused by Xylella fastidiosa, is a disease of mulberry trees in the United States that has largely been documented from locations in the eastern and central areas of the country. MLS was recently detected for the first time in white mulberry (Morus alba) trees in southern California. Four MLS-strains were isolated from two locations and confirmed as $X$. fastidiosa by enzyme-linked immunosorbent assay (ELISA), direct isolation of the pathogen, and use of the $X$. fastidiosa-specific PCR primers RST31-33. Isolated strains were characterized by the sequencing of their 16S-23S rDNA intergenic spacer regions (ISR) and random amplified polymorphic DNA (RAPD) analysis and subsequent comparison with a previously characterized MLS-strain (Mulberry-VA) and representatives of X. fastidiosa subsp. fastidiosa, X. fastidiosa subsp. multiplex, and X. fastidiosa subsp. sandyi. MLS-strains isolated from California were distinct from strains causing almond leaf scorch, oleander leaf scorch, and Pierce's disease and similar to the Mulberry-VA-strain. The ISR sequences of two MLS-strains, MLS063 and MLS059, were $100 \%$ identical to that of the Mulberry-VA sequence, whereas MLS012 and MLS024 were 99.8 and $99.6 \%$ identical to the Mulberry-VA-strain and $99.4 \%$ identical among themselves. Genomic analysis using RAPD revealed no differences among the four strains. The pathogenicity of one strain, MLS063, was confirmed by inoculation of glasshouse-grown white mulberry plants. Three months after inoculation, the pathogen was recovered from 21 of 25 inoculated plants, and 5 of 25 plants were dead within a year of inoculation. Inoculation of grapevines and oleanders with MLS063 did not result in any disease or recovery of the pathogen up to 1 year later, showing that this strain was not cross-infective to these hosts.
\end{abstract}

Additional keywords: glassy-winged sharpshooter, phylogenetic analysis

Xylella fastidiosa (40) is a gramnegative, xylem-limited, nutritionally fastidious, nonflagellate bacterium. It can infect a broad range of plants from diverse taxonomic groups including both monocotyledonous and dicotyledonous species. Many host plants can have symptomless infections, whereas others can be severely affected by scorch, stunt, dieback, or wilt. Economically important diseases caused by $X$. fastidiosa include Pierce's disease in grapes (PD) (9), almond leaf scorch (ALS) (24), phony peach (41), plum leaf scald (29), oleander leaf scorch (OLS) (28), and citrus variegated chlorosis (4). X. fastidiosa is also widespread in landscape and shade tree populations and has been isolated from the xylem tissue of diseased American elm (19), red oak (5), American sycamore (34), red maple (14), and red

Corresponding author: F. P. Wong

E-mail: frank.wong@ucr.edu

Accepted for publication 11 April 2006.

DOI: 10.1094/PD-90-1143

C) 2006 The American Phytopathological Society mulberry (20). The primary mode of pathogen spread is by xylem sap-feeding insects from infected plants to other plants $(1,27)$. Once $X$. fastidiosa has infected a host, there are limited or no therapeutic options for the infected plant; thus, the identification, quarantine, and removal of alternative hosts has been suggested as a possible management technique (35).

In California, the recent introduction of the glassy-winged sharpshooter (GWSS), Homalodisca coagulata, has resulted in the rapid spread of $X$. fastidiosa among both grapevine and oleander $(2,7)$. Due to the wide host range of the vector, a large number of plant species are at risk in southern California for infection by $X$. fastidiosa $(3,36,39)$.

In 2003 and 2004, a survey was conducted to determine the host range and genetic diversity of $X$. fastidiosa populations in landscape plants in urban areas of southern California. During the survey, a number of white mulberry (Morus alba L.) trees showing scorch and dieback symptoms were found, and X. fastidiosa was suspected as a causal agent. White mulberry is native to China and was imported to North America in the 1700 s and is es- tablished as a common landscape tree throughout California. They are used as shade trees and windbreaks and in some locations, white mulberry is considered a nonindigenous weed that grows well in roadsides and abandoned areas due to its tolerance of drought and poor soils. Other mulberry species, including red (M. rubra L., native to the northeastern United States), black (M. nigra L., native to western Asia), and the various cultivated hybrids, are present in California, but white mulberry is the dominant landscape species. Mulberry leaf scorch (MLS), caused by $X$. fastidiosa, had never been reported in California on any mulberry species.

There is only limited information on the biology and geographical range of MLS in the United States. The disease is manifested as marginal leaf scorch and dieback of twigs and branches. MLS affects both red and white mulberry, two common species in the United States. The disease was first reported in red mulberry in 1986 from Delaware, Maryland, New Jersey, New York, and Pennsylvania (21). It also appears to be present on red mulberry in Massachusetts (40) and in Nebraska in both red and white mulberry (6). Analysis of the genetic relationship of MLS-strains with others $X$. fastidiosa strains has shown that MLS-strains are more closely related to PD-strains than to citrus, oak, elm, almond, plum, peach, or maple strains $(6,18,26)$, but evidence of cross-infectivity data between MLS-strains and PD-strains has not been shown. Recent studies have subdivided $X$. fastidiosa into a number of subspecies (31,32): X. fastidiosa subsp. fastidiosa includes strains isolated from cultivated grape (Vitis vinifera), alfalfa (Medicago sativa), maple (Acer sp.), almond (Prunus dulcis), and some weeds (8). Cross inoculation with $X$. fastidiosa subsp. fastidiosa strains isolated from grape, almond, and alfalfa generally results in disease, suggesting the lack of pathovars within that subspecies (31). X. fastidiosa subsp. multiplex includes strains isolated from peach (Prunus persica), elm (Ulmus sp.), plum (Prunus domestica), pigeon grape (Vitis aestivalis), almond (Prunus dulcis), sycamore (Platanus occidentalis), and other shade trees (31). Cross inoculation with strains of $X$. fastidiosa subsp. multiplex from different hosts does not always result in disease $(13,33)$, suggesting that pathovars with restricted host ranges 
may exist (31). X. fastidiosa subsp. pauca includes strains isolated from citrus (Citrus sinensis) (31) and coffee (Coffea arabica) $(12,22)$. There has also been a suggestion for a new subspecies called sandyi that includes strains isolated from oleander (Nerium oleander) (32). Currently, strains from mulberry causing MLS have not been characterized into any of these groups.

The objectives of this work were to (i) isolate $X$. fastidiosa from scorch-affected mulberries, (ii) characterize these new strains by analysis of the 16S-23S rDNA intergenic spacer (ISR) sequences and the use of random amplified polymorphic DNA-polymerase chain reaction (RAPDPCR), and (iii) confirm the pathogenicity of isolated strains to mulberry as well as oleander and grapevine to ensure that these uncharacterized strains do not share the host range of known PD and OLS strains. The discovery of MLS or MLS-like diseases caused by $X$. fastidiosa in California may point to spread of new diseases in the state due to the appearance of GWSS and may be an indication of an increase in other economically important diseases caused by this pathogen.

\section{MATERIALS AND METHODS}

Collection of samples. In 2003 and 2004 , a survey project aimed at characterizing landscape and ornamental hosts of $X$. fastidiosa in southern California was performed. Five urban locations in southern California where the pathogen and GWSS were known to be common were targeted, encompassing an area approximately $15,000 \mathrm{~km}^{2}$ in size: Fillmore (Ventura County), Redlands (San Bernardino County), Riverside (Riverside County), San Diego (San Diego County), and Tustin (Orange County). Starting from a central location in these cities, all plants with typical $X$. fastidiosa symptoms (scorch, stunt, dieback, wilt, etc.) were sampled. Typically, a single sampling run covered an approximate area of $10 \mathrm{~km}^{2}$. Samples were placed into individual plastic bags and processed for enzyme-linked immunosorbent assay (ELISA) and bacterial isolation as described below within 24 to $48 \mathrm{~h}$ of sampling. A total of 1,670 samples representing 161 plant species were taken from symptomatic plants in the five locations. A total of 591 samples $(35 \%)$ representing 102 identified species $(63 \%)$ tested posi-
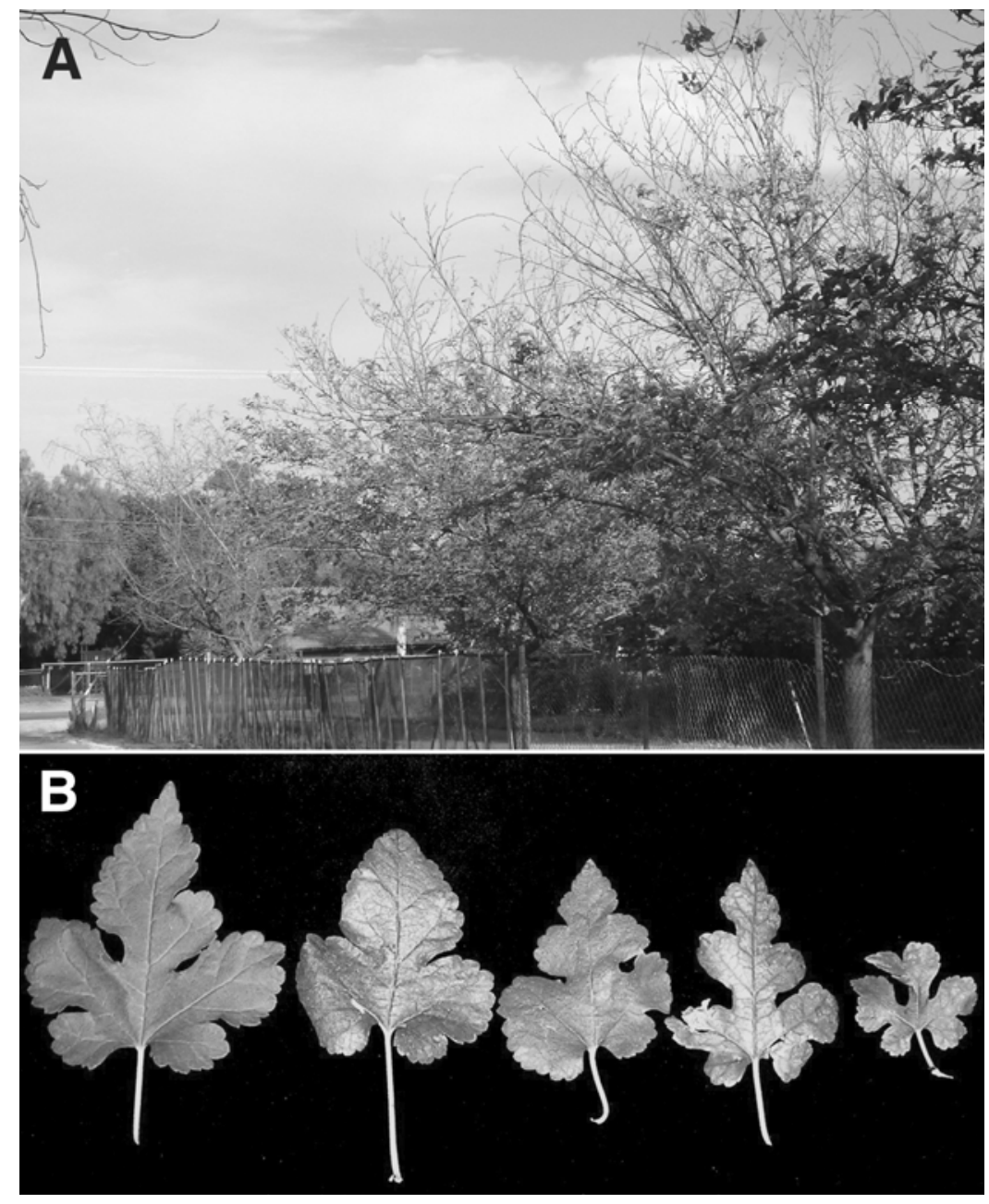

Fig. 1. Symptoms of mulberry leaf scorch: A, scorch and dieback symptoms on white mulberry (Morus alba) in southern California; B, symptomatic leaves of mulberry plants mechanically inoculated with Xylella fastidiosa, showing chlorosis and marginal scorching as compared with a healthy leaf (far left).

tive. Among samples testing positive were one white mulberry tree located in Riverside, one located in Santa Ana, and nine in Redlands, which exhibited typical scorch symptoms (Fig. 1).

ELISA of symptomatic mulberry plants. To test for the presence of $X$. fastidiosa, samples were assayed using the PathoScreen Kit (Agdia Inc., Elkhart, IN). Briefly, 2- to 3-cm-long sections of leaf petioles and midvein were cut from leaves, and approximately $0.2 \mathrm{~g}$ was macerated in $1 \mathrm{ml}$ of extraction buffer in plastic sample bags (Agdia). Enough tissue was reserved and set aside at room temperature for the isolation of the pathogen, as described below. Tissue from healthy glasshousegrown grapevine and oleander were used as negative controls. One-hundred microliters of each sample was loaded into 96well microtiter plates coated with $X$. fastidios $a$-specific antibodies and processed. The results of the analysis were read on a Benchmark microtiter plate reader (BioRad, Hercules, CA) at a wavelength of 490 $\mathrm{nm}$. Samples were considered positive if the absorbance was greater than two times the average of the negative controls.

Isolation of $X$. fastidiosa from mulberry plants. For samples testing positive with ELISA, attempts were made to isolate and culture $X$. fastidiosa from the remaining sample tissue. Isolations were made using both PD3 (10) and PW (11) media in 6-cm-diameter sterile petri dishes (Fisher Scientific, Pittsburgh, PA). In both media, agar was substituted with $0.8 \%$ of gelrite (Sigma Chemical Co., St. Louis, MO). Samples were prepared as follows: a 2- to 3 -cm-long section of leaf petioles and midvein were cut from leaves, surfacesterilized by soaking for $2 \mathrm{~min}$ in $95 \%$ ethanol, 2 min in $20 \%$ bleach (1:5 dilution of a $5.25 \%$ bleach solution), then rinsed twice for $2 \mathrm{~min}$ in sterile-distilled water. The washed plant tissue was sliced crosswise into fine sections about 2 to $3 \mathrm{~mm}$ wide in $100 \mu \mathrm{l}$ of sterile PBS buffer (10 $\mathrm{mM}$ phosphate buffer, $\mathrm{pH} 7.4,150 \mathrm{mM}$ $\mathrm{NaCl}$ ) using flame-sterilized razor blades and forceps. The tissue was soaked in PBS at room temperature for $10 \mathrm{~min}$, then $45 \mu \mathrm{l}$ of liquid was transferred to each type of specialized media plates using a micropipette, and the liquid was distributed over the surface by tilting the plate. Plates were incubated at $28^{\circ} \mathrm{C}$ and inspected for colony growth 1,2, and 6 weeks after extraction. Bacterial colonies with typical morphology of $X$. fastidiosa were subcultured to new PD3 and PW media for PCR-identification as described below.

Confirmation as $X$. fastidiosa by PCR. The identity of putative $X$. fastidiosa colonies was confirmed by PCR using the RST31 and RST33 primer pair (23). For consistency and ease of amplification, Ready-to-go PCR beads (Amersham Pharmacia Biotech Inc., Piscataway, NJ) were used for amplification (final concen- 
tration: $10 \mathrm{mM}$ Tris- $\mathrm{HCl}, 50 \mathrm{mM} \mathrm{KCl}, 1.5$ $\mathrm{mM} \mathrm{MgCl}_{2}$, dNTP mix at $200 \mu \mathrm{M}$ each, and $3 \mathrm{U}$ of Taq DNA polymerase). Bacteria from a single putative $X$. fastidiosa colony (approximately 1 to $2 \mathrm{~mm}$ in diameter) was picked from the media using a sterile, autoclaved toothpick and placed into a 0.3$\mathrm{ml}$ microcentrifuge tube containing one Ready-to-go PCR bead, $0.25 \mu$ of each primer $(25 \mathrm{pM} / \mu \mathrm{l}$ solution), and sufficient sterile double-distilled water to obtain 25 $\mu \mathrm{l}$ of total reaction volume. Bacterial concentration was not standardized.

Amplification was performed in a thermal cycler (GeneAmp PCR System 9700, PE Applied Biosystems) programmed to execute the following protocol: $95^{\circ} \mathrm{C}$ for 5 min, followed by 40 cycles of $94^{\circ} \mathrm{C}$ for 40 $\mathrm{s}, 55^{\circ} \mathrm{C}$ for $40 \mathrm{~s}, 72^{\circ} \mathrm{C}$ for $1 \mathrm{~min}$, and a final cycle at $72^{\circ} \mathrm{C}$ for $5 \mathrm{~min}$, then held at $4^{\circ} \mathrm{C}$. Gel electrophoresis was performed on products in $1 \%$ agarose-Tris borate EDTA gels (TBE) (89 mM Tris, $89 \mathrm{mM}$ boric acid, $2 \mathrm{mM}$ EDTA, pH 8.0) and stained using ethidium bromide $(0.5 \mu \mathrm{g} / \mathrm{ml}$ gel $)$ to visualize product. Isolates from which the 733-bp product was amplified were considered $X$. fastidiosa-positive. Bacteria from these colonies were then transferred to fresh PW and PD3 medium plates for continued growth. For long-term storage, bacterial cells were harvested from petri dishes and maintained in PW broth with $20 \%$ glycerol at $-80^{\circ} \mathrm{C}$. Isolates confirmed as $X$. fastidiosa-positive were subject to additional PCR analyses for characterization of strain identity.

Characterization of Xylella strains by analysis of the 16S-23S rDNA intergenic spacer region (ISR). For extraction of genomic DNA, bacterial cultures were grown for 7 to 14 days on PD3, and DNA was extracted with a Qiagen DNeasy Tissue Kit (Qiagen Inc., Valencia, CA) and resuspended in TE $(10 \mathrm{mM}$ Tris- $\mathrm{HCl}$ and 1 $\mathrm{mM}$ EDTA, $\mathrm{pH}$ 7.4) to a final concentration of $50 \mathrm{ng} / \mu \mathrm{l}$. Extracted DNA from $X$. fastidiosa strains was used as template for amplification of the 16S-23S rDNA ISR using primers G1 (5'-GAAGTCGTAACA-
AGG-3') and L1 (5'-CAAGGCATCCACCGT-3') as described previously (15). The PCR-amplified products were electrophoresed and purified from the agarose gel using the QIAquick Gel Extraction Kit (Qiagen). Purified fragments were cloned using the pGEM-T Easy Vector System (Promega Corp., Madison, WI), and then sequenced. ISR sequences were compared with those from known ALS, MLS, OLS, and PD strains. The GenBank accession numbers of the amplified rDNA ISR sequences for all of the strains used in the study are given in Table 1 . Sequences were aligned using the ClustalX program (38), and their relationships were resolved using maximum parsimony analysis with the PAUP* v4 software program (37). The strength of the tree topology was assessed by bootstrapping 1,000 times, and the tree was constructed with the TreeView program (25).

RAPD-PCR. RAPD-PCR analysis was performed on the isolates collected from this study as well as known ALS (276, Dixon, ALS2, ALS1, Tulare), OLS (Texas, Riverside3, Ann1), and PD (A05, STL, Preston Ranch) strains (Table 1). The analysis was performed using 10-base primers: OP-AA-06 (GTGGGTGCCA), OP-AA-04 (AGGACTGCTC), OP-AA-09 (AGATGGGCAG), OP-AA-02 (GAGACCAGAC), OP-AA-03 (TTAGCGCCCC), and OP-AA-11 (ACCCGACCTG) (15). Amplifications were done in a $25-\mu$ reaction volume containing $50 \mathrm{ng}$ of genomic DNA (extracted from bacterial strains as described above), 25 pmol of a single primer, a Ready-to-go PCR bead, and the suitable water. Amplification was performed in a thermal cycler (GeneAmp PCR System 9700) programmed to execute the following protocol: $94^{\circ} \mathrm{C}$ for $1 \mathrm{~min}$, followed by 45 cycles of $94^{\circ} \mathrm{C}$ for $1 \mathrm{~min}$, $34^{\circ} \mathrm{C}$ for $1 \mathrm{~min}, 72^{\circ} \mathrm{C}$ for $2 \mathrm{~min}$, and a final cycle at $72^{\circ} \mathrm{C}$ for $5 \mathrm{~min}$, then held at $4^{\circ} \mathrm{C}$. Gel electrophoresis was performed on products in $2 \%$ agarose-TBE and stained using ethidium bromide $(0.5 \mu \mathrm{g} / \mathrm{ml}$ gel $)$ to visualize product. Photographs from ethidium bromide stained agarose gels were used to score RAPD data for analysis. Each amplification band was treated as a unit character and was scored as 1 (present) or 0 (absent) for all strains. Bands with the same mobility were considered to be identical fragments. Analyses were performed using PAUP* 4.0b2a software (37). Data matrices were used to compute genetic distances between strains using the Jaccard similarity method, and the distance matrices were used to construct phylograms with the unweighted pair group method average (UPGMA). The strength of the tree topology was assessed by bootstrapping 1,000 times, and the tree was constructed with the TreeView program (25).

Mechanical inoculations. For inoculations, three strains were chosen: MLS063, isolated from a symptomatic white mulberry tree; A05, a PD-strain obtained from a grapevine in the Temecula Valley area (8); and Riverside3, an OLS-strain isolated from oleander in Riverside, CA. MLS063 was arbitrarily chosen from the strains collected, whereas A05 and Riverside3 were strains representative of known PD and OLS types. Cultures of X. fastidiosa were grown on PW medium for 7 days at $28^{\circ} \mathrm{C}$ and resuspended in $2 \mathrm{ml}$ of $\mathrm{pH} 7$ PBS solution to obtain a turbid solution of approximately $1 \times 10^{8} \mathrm{X}$. fastidiosa cells per $\mathrm{ml}$ or higher.

White mulberry and oleander plants were obtained from a commercial nursery in San Dimas, CA, as small liner-sized rooted cuttings in $5 \times 5 \times 20 \mathrm{~cm}$ containers. Grapevines (V. vinifera 'Chardonnay') were grown from dormant cuttings obtained from the University of California Foundation Plant and Materials Service in Davis; rooted cuttings were approximately 2 months old. To ensure that all plants were not already infected with $X$. fastidiosa before being used in inoculation studies, all plants were tested with ELISA as described above. Plants were potted in 3.8-liter plastic pots filled with University of California soil mix and watered four

Table 1. Strains of Xylella fastidiosa used in this study: host sources and GenBank accession numbers for 16S-23S rDNA intergenic spacer region sequences

\begin{tabular}{|c|c|c|c|c|c|}
\hline Strain designation & Strain type ${ }^{a} /$ subspecies & Host & Strain origin & GenBank accession no. & Source \\
\hline 276 & ALS/multiplex & Almond & California & AY603084 & (8) \\
\hline Dixon & ALS/multiplex & Almond & California & AF073251 & (15) \\
\hline ALS2 & ALS/multiplex & Almond & California & AF073243 & (15) \\
\hline ALS1 & ALS/fastidiosa & Almond & California & AF073240 & (15) \\
\hline Tulare & ALS/fastidiosa & Almond & California & AF073242 & (15) \\
\hline Preston Ranch & PD/fastidiosa & Grapevine & California & AF073232 & (15) \\
\hline A05 & $\mathrm{PD} /$ fastidiosa & Grapevine & California & AY603090 & (8) \\
\hline STL & $\mathrm{PD} /$ fastidiosa & Grapevine & California & AF073228 & (15) \\
\hline MLS012 & MLS & Mulberry & California & DQ415377 & This study \\
\hline MLS024 & MLS & Mulberry & California & DQ415376 & This study \\
\hline MLS059 & MLS & Mulberry & California & DQ415378 & This study \\
\hline MLS063 & MLS & Mulberry & California & DQ415379 & This study \\
\hline Mulberry-VA & MLS & Mulberry & Virginia & AY196794 & (18) \\
\hline Texas & OLS/sandyi & Oleander & Texas & DQ011263 & (16) \\
\hline Riverside3 & OLS/sandyi & Oleander & California & DQ011264 & (16) \\
\hline Ann1 & OLS/sandyi & Oleander & California & AF073215 & (15) \\
\hline
\end{tabular}

a ALS = almond leaf scorch; PD = Pierce's disease; MLS = mulberry leaf scorch; OLS = oleander leaf scorch. 
times a week as needed. Plants were maintained in glasshouses at ambient environmental conditions (approximately 20 to $30^{\circ} \mathrm{C}$ ) for the duration of the experiment. Plants were allowed to grow for approximately 2 to 3 months in the 3.8 -liter pots before being used in inoculation studies.

In August 2004, clean plants were inoculated by pipetting a small drop of the bacterial solution onto a stem and probing the drop with a \#1 insect pin (Indigo Instruments, Tonawanda, NY) until uptake of the drop was observed (17). Plants were inoculated at the base of the main stem and at the branch points, approximately six to eight inoculations were made per plant, and inoculation points were marked with string tied loosely to the plant. The MLS063 strain was inoculated into 25 mulberries, 25 grapevine, and 15 oleander plants. A05 and Riverside3 strains were inoculated into 25 grapevine or 25 oleander plants, respectively, and served as positive controls for the inoculation process. Ten of each plant species were inoculated with PBS only to serve as negative controls. Every 3 months after inoculation for a year, three petioles from each of the inoculated plants were tested by ELISA (as described above); direct isolation of $X$. fastidiosa from ELISA-positive and some control plants was also performed from the sampled petioles on both PD3 and PW media. Petioles of fully expanded leaves were taken randomly from locations distal from the inoculation points.

\section{RESULTS}

Identification of $X$. fastidiosa from symptomatic mulberry trees. During the survey conducted in 2003 and 2004, a total of 19 symptomatic white mulberry trees were tested and 11 were ELISA-positive for $X$. fastidiosa. Isolation of the pathogen was successful only from four positive trees sampled in 2004, one from Riverside the others from Redlands. From these samples, bacterial colonies typical of $X$. fastidiosa were observed approximately 15 days after incubation on both PW and PD3 media supplemented with gelrite; a total of four strains were isolated. PCR with the $X$. fastidiosa-specific primers RST31 and RST33 revealed the 733-bp product from all four isolates, confirming their identity as $X$. fastidiosa.

Strain identification. Based upon 16S23S rDNA ISR sequence and RAPD-PCR analyses, the four isolates from white mulberry were all identified as MLS-strains of $X$. fastidiosa and given the putative designations of MLS024 (Riverside), MLS012, MLS063, and MLS059 (Redlands). The sequences of the 16S-23S rDNA ISR of $X$.

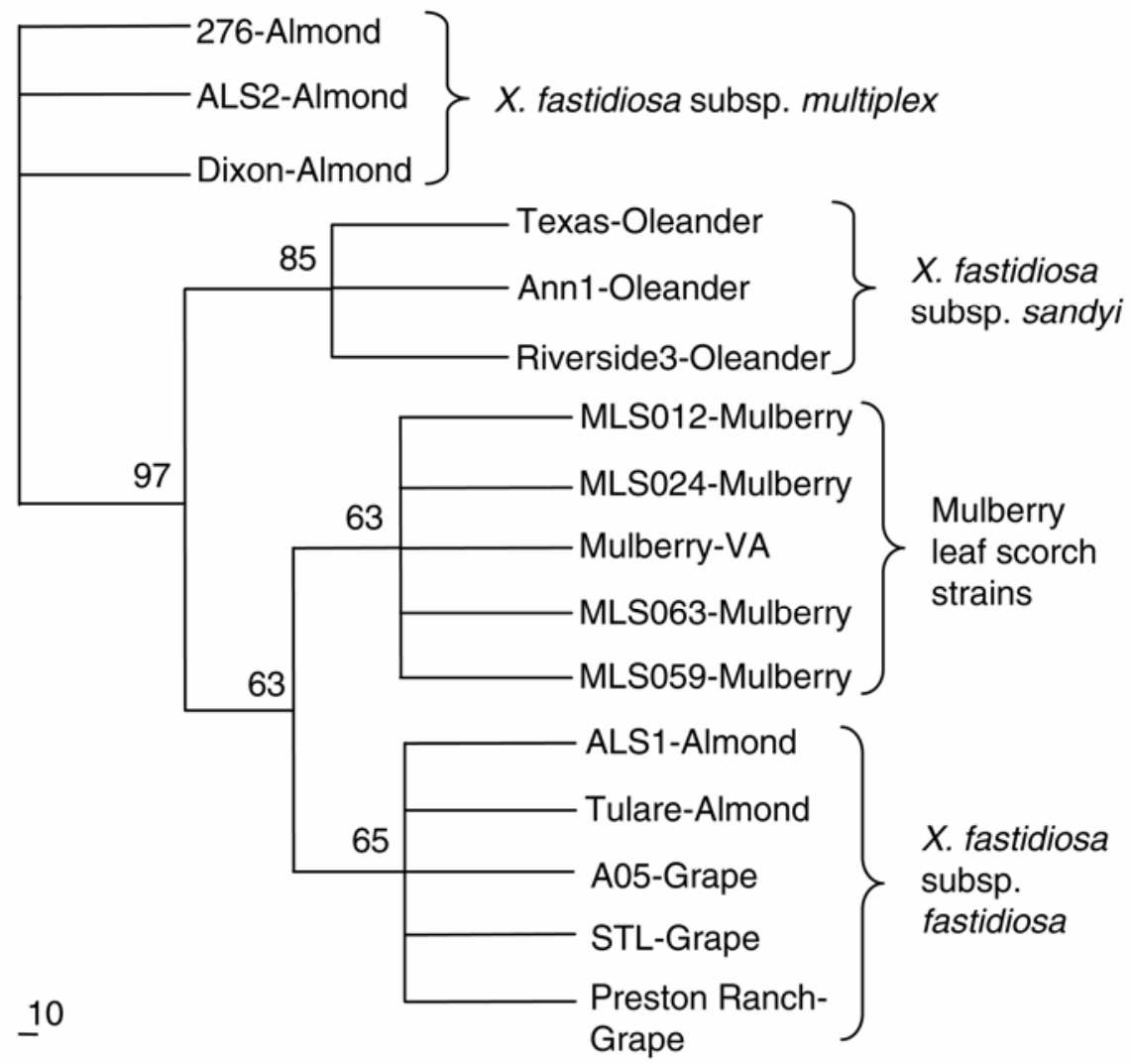

Fig. 2. Phylogenetic tree generated with PAUP* 4.0b2a Software based on 16S-23S rDNA intergenic spacer region (ISR) sequence data for Xylella fastidiosa strains. Heuristic maximum parsimony searches were executed in 1,000 replicates with all characters unordered and equally weighted. The strength of the tree topology was assessed by bootstrapping 1,000 times. Numbers above branches represent bootstrap percentage values obtained for 1,000 replicates. Detailed descriptions of strains are given in Table 1. fastidiosa strains isolated from mulberry appeared to be very similar to previously described MLS-strains. Alignment of the ISR sequences from the collected strains with the Mulberry-VA-strain isolated from Virginia (18), revealed $100 \%$ identity among the MLS063, MLS059, and Mulberry-VA strains. MLS024 and MLS012 showed a 99.6 and $99.8 \%$ identity, respectively, with Mulberry-VA-strain and a $99.4 \%$ between them. A phylogenetic tree was constructed based on the ISR sequences of the four MLS-strains, the Mulberry-VA-strain, and 11 other selected $X$. fastidiosa strains obtained from the databank (Fig. 2). The phylogenetic analysis indicated that all the California mulberry strains from this study are genetically comparable among themselves and with the Mulberry-VA-strain.

RAPD-PCR analysis revealed identical banding patterns among the new mulberry strains (Fig. 3) but a number of differences compared with the PD, OLS, and ALS strains tested. The phylogenetic tree constructed using RAPD-PCR separated the MLS-strains as a distinct group from the other strains tested (Fig. 4).

Pathogenicity tests. Three months after mechanical inoculation, 21 of 25 mulberry plants inoculated with MLS-strain MLS063 tested positive by ELISA (Table 2). Similarly, for grape and oleander plants inoculated at the same time with a PD and OLS strain, respectively, 25 and 22 plants tested positive for $X$. fastidiosa (Table 2), indicating that mechanical inoculation of mulberry with an MLS-strain was as successful as for the pathogen to oleander and grapevine.

Subsequent isolations from mulberry plants testing positive by ELISA resulted in the successful recovery of $X$. fastidiosalike colonies on both PD3 and PW media. These colonies were confirmed as $X$. fastidiosa by successful amplification of the diagnostic 733-bp PCR product using the RST-31/33 primer set. Like the MLS063inoculated plants, $X$. fastidiosa was recovered from some grapevines and oleander plants testing positive by ELISA; bacteria recovered on PD3 and PW media were also positive by PCR using the RST-31/33 primer set (Table 2). To confirm the identity of the recovered isolates from mulberries, the $16 \mathrm{~S}-23 \mathrm{~S}$ ISR sequences of selected single colonies were amplified, cloned and sequenced, and aligned with the sequence previously obtained from MLS063. Sequences from the recovered isolates were identical to that of MLS063 (data not shown).

Mulberry plants started showing leaf scorch symptoms approximately 5 months after inoculation with MLS063. After 6 months, leaves dropped and the new shoots and leaves were chlorotic and malformed. One year after inoculation, five plants were dead. All 25 grapevines inoculated with A05 and 15 oleanders inoculated with Riverside3 were dead 9 months after in- 
oculation. Inoculation of grapevine and oleander with MLS063 did not result in any disease development or the recovery of $X$. fastidiosa from these plants after 3, 6, 9, or 12 months. One grapevine and one oleander plant did test positive by ELISA at the 3-month test, but tests were negative afterward and no disease symptoms developed, suggesting either a false-positive or the inability of the bacteria to successfully systemically infect the host. None of the PBS-inoculated plants tested positive for $X$. fastidiosa or showed any symptoms after 1 year.

\section{DISCUSSION}

In this study, we report the presence of mulberry leaf scorch and MLS-strains of $X$. fastidiosa for the first time in California. Four isolates recovered from symptomatic white mulberry in southern California were confirmed to be MLS-type based upon 16S-23S rDNA ISR sequence, RAPD-PCR analysis, and host pathogenicity studies.

With regard to classification as a subspecies, MLS-strains of X. fastidiosa have not yet been characterized; these were not evaluated in two recent studies $(31,32)$. It would appear that MLS-strains could represent a unique subspecies due to their separation from the ALS, OLS, and PD strains used in this study, but the specific work needed to confirm this is yet to be completed. MLS-strains isolated in California appear not to be different from a previously reported MLS-strain (MulberryVA) based upon ISR sequencing, RAPD analysis, and host-specificity. As described previously, our MLS-strains are more closely related to PD-strains than ALSstrains $(6,18,26)$, but the phylogenetic analysis showed some differences in relationships from the OLS and PD group, dependent upon the methodology used (ISR sequences or RAPD analysis). Regardless, the MLS-strains isolated here were shown to be a distinct group by either analysis and were shown to be unable to infect grape or oleander, indicating that the California strains of MLS are likely very similar to those described previously. At the time of the study, it had been suggested from certain works in progress $(30,32)$ that recent recombination among strains in California may have led to alterations in host range; thus the MLS-strains were tested for pathogenicity on grapevine and oleander to assess that threat. Our results did not suggest that this is the case at this time for the MLS-strains examined, but a larger population of $X$. fastidiosa isolates from different hosts should be examined in the future. Nevertheless, the role of MLSstrains in causing disease in other ornamentals or economically important crops is still not completely understood, as we are still discovering new $X$. fastidiosa diseases in southern California landscapes, and additional pathogenicity tests should be performed with other nonmulberry hosts to confirm this (42).

The presence of MLS-strains in California suggests that previously undescribed $X$.

fastidiosa strains may already be in California, and there is a potential for the rise of a number of $X$. fastidiosa diseases in both agricultural and urban plants. Mul-
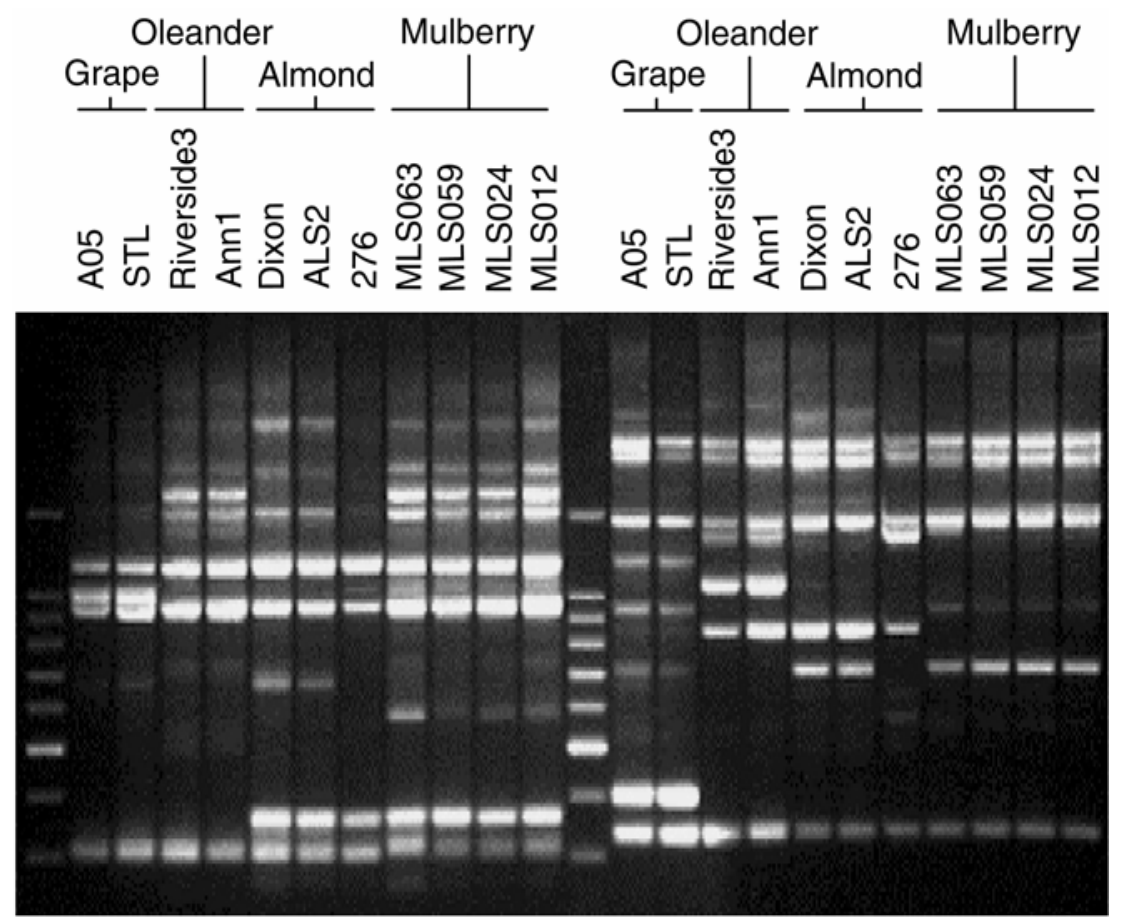

Fig. 3. Random amplified polymorphic DNA amplification products of Xylella fastidiosa strains isolated from mulberry, grapevine, almond, and oleander. The 10-base primers used were OPA09 (AGATGGGCAG) and OPA11 (ACCCGACCTG). First and middle lanes are 100-bp DNA molecular size ladder.

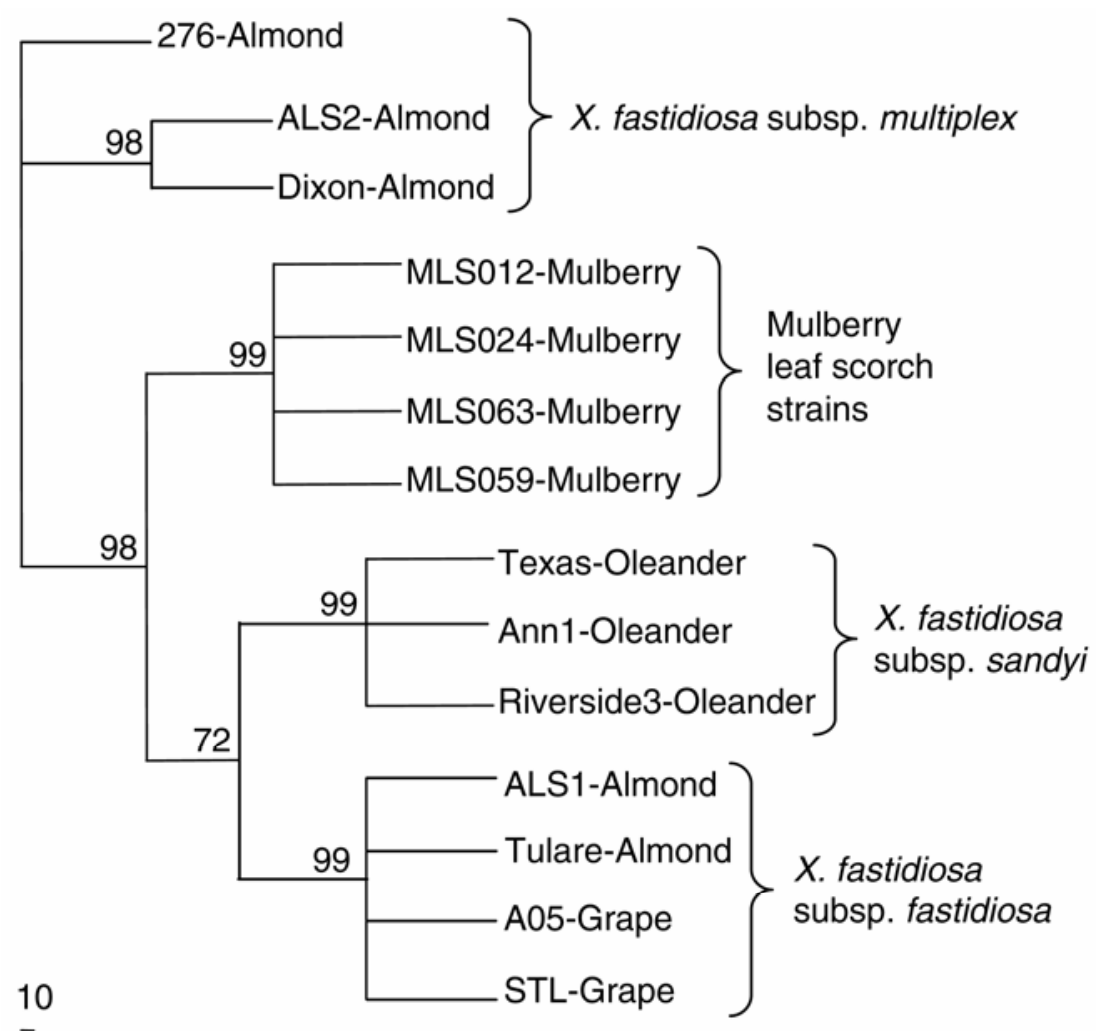

Fig. 4. Phylogenetic tree based on random amplified polymorphic DNA-polymerase chain reaction (RAPD-PCR) analysis data of Xylella fastidiosa strains. A genetic distance matrix was obtained using the computer software PAUP* 4.0b2a and subsequently used to construct dendrograms using the unweighted pair group method average (UPGMA). Numbers above branches represent bootstrap percentages obtained from 1,000 replicates. See Table 1 for strain details. 
Table 2. Evaluation of pathogenicity tests for mulberry, grapevine, and oleander plants inoculated with Xylella fastidiosa strains MLS063, A05, and Riverside3

\begin{tabular}{|c|c|c|c|c|c|c|}
\hline \multirow[b]{2}{*}{$X$. fastidiosa strain } & \multirow[b]{2}{*}{ Inoculum source } & \multirow[b]{2}{*}{ Test plant } & \multirow[b]{2}{*}{ Number inoculated } & \multicolumn{3}{|c|}{ Number of positive plants ${ }^{a}$} \\
\hline & & & & ELISA & Culture & PCR \\
\hline MLS063 & Mulberry & Mulberry & 25 & 21 & 21 & 21 \\
\hline MLS063 & Mulberry & Grapevine & 25 & 1 & 0 & 0 \\
\hline MLS063 & Mulberry & Oleander & 15 & 1 & 0 & 0 \\
\hline A05 & Grapevine & Grapevine & 25 & 25 & 12 & 12 \\
\hline Riverside3 & Oleander & Oleander & 25 & 22 & 22 & 22 \\
\hline Control & PBS buffer & Mulberry & 10 & 0 & 0 & 0 \\
\hline Control & PBS buffer & Grapevine & 10 & 0 & 0 & 0 \\
\hline Control & PBS buffer & Oleander & 10 & 0 & 0 & 0 \\
\hline
\end{tabular}

${ }^{a}$ Number of plants testing positive for the presence of $X$. fastidios $a$ based on the number of plants inoculated using enzyme-linked immunosorbent assay (ELISA), direct culturing on PD3 and PW media, and RST31-33 primers for polymerase chain reaction (PCR) analysis.

berry is a known host of GWSS is California (3), but no MLS had been reported previously in California. It is possible that the strain has been in California for a long time but had been overlooked or mistaken for abiotic stress, and it was not until after the arrival of GWSS that the disease appeared to become more prevalent. Although other sharpshooter vectors such as the blue-green sharpshooter (Graphocephala atropunctata) (27) have been known to vector $X$. fastidiosa in southern California, GWSS is likely to be contributing to the spread of the bacteria in the urban environment, since it has been shown to be an efficient vector of $X$. fastidiosa $(2,7)$ and at present has a host list of more than 230 plant species according to the California Department of Food and Agriculture Pierce's Disease Control Program (3).

In recent years, $X$. fastidiosa diseases have increased in California, with recent outbreaks of Pierce's disease occurring in southern California and a rise in the incidence of oleander leaf scorch. Although not specifically addressed here, the number of landscape trees and ornamentals affected by $X$. fastidiosa-like diseases appears to be increasing. The recent rise in disease is correlated with the introduction of GWSS to southern California.

From a practical standpoint, we now know that MLS is a disease to be considered when it comes to the selection of mulberry as a landscape ornamental and that this disease should be looked for in nursery stock to limit the propagation of infected materials. Although our MLSstrains were only isolated from white mulberry, it is likely that red mulberry is at risk based on the similarity of California strains with the Mulberry-VA-strain and the presence of the disease on that species in the eastern and central United States $(6,21,40)$. The susceptibility of black mulberry, interspecies hybrids, or varieties of the different species is not known, but these may also be at risk in California. With regard to detection of $X$. fastidiosa in plants for control and quarantine purposes, the wide range of $X$. fastidiosa subspecies should be addressed since there are a potential number of $X$. fastidiosa subspecies or strains with different host ranges in California that cannot be adequately identified by ELISA or nonspecific PCR (23) techniques (42). Thus, the development of rapid subspecies and strain-specific characterization techniques should be explored.

The appearance of new strains of $X$. fastidiosa in California such as MLS signals the potential rise of $X$. fastidiosa diseases throughout the state not only on crops of economic importance, but also on ornamentals, landscapes, and amenity trees. Further characterization of new strains and diseases caused by $X$. fastidiosa is important for implementing control measures to limit the spread of the epidemic in California. The overall impact of this pathogen on the California landscape and economy remains to be seen, but it does appear that new $X$. fastidiosa diseases in California will continue to emerge until effective control measures are developed.

\section{ACKNOWLEDGMENTS}

Funding for this research was provided by the CDFA Pierce's Disease and Glassy-winged Sharpshooter Control Program. The authors would like to thank K. de la Cerda, J. C. Rios, and A. Guzman for their help and contributions.

\section{LITERATURE CITED}

1. Adlerz, W. C., and Hopkins, D. L. 1979. Natural infectivity of 2 sharpshooter Oncometopia nigricans Homalodisca coagulata vectors of Pierce's disease of grape Vitis-vinifera cultivar Carignane in Florida USA. J. Econ. Entomol. 72:916-919.

2. Almeida, R. P., and Purcell, A. H. 2003. Transmission of Xylella fastidiosa to grapevines by Homalodisca coagulata (Hemiptera: Cicadellidae). J. Econ. Entomol. 96:264-271.

3. California Department of Food and Agriculture. 2005. Plant Quarantine Manual, Pest Exclusion, Plant Health and Pest Prevention Services. Calif. Dep. Food Agric., Sacramento, CA.

4. Chang, C. J., Garnier, M., Zreik, L., Rossetti, V., and Bove, J. M. 1993. Culture and serological detection of the xylem-limited bacterium causing citrus variegated chlorosis and its identification as a strain of Xylella fastidiosa. Curr. Microbiol. 27:137-142.

5. Chang, C. J., and Walker, J. T. 1988. Bacterial leaf scorch of northern red oak: Isolation, cultivation, and pathogenicity of a xylem-limited bacterium. Plant Dis. 72:730-733.

6. Chen, J. C., Hartung, J. S., Chang, C. J., and Vidaver, A. K. 2002. An evolutionary perspective of Pierce's disease of grapevine, citrus variegated chlorosis, and mulberry leaf scorch diseases. Curr. Microbiol. 45:423-428.

7. Costa, H. S., Blua, M. S., Bethke, J. A., and Redak, R. A. 2000. Transmission of Xylella fastidiosa to oleander by the glassywinged sharpshooter, Homalodisca coagulata. HortScience 35:1265-1267.

8. Costa, H. S., Raetz, E., Pinckard, T. R., Gispert, C., Hernandez-Martinez, R., Dumenyo, C. K., and Cooksey, D. A. 2004. Plant hosts of Xylella fastidiosa in and near southern California vineyards. Plant Dis. 88:1255-1261.

9. Davis, M. J., Purcell, A. H., and Thomson, S. V. 1978. Pierce's disease of grapevines isolation of the causal bacterium. Science 199:75-77.

10. Davis, M. J., Purcell, A. H., and Thomson, S. V. 1980. Isolation media for the Pierce's disease bacterium. Phytopathology 70:425-429.

11. Davis, M. J., Raju, B. C., Brlansky, R. H., Lee, R. F., Timmer, L. W., Norris, R. C., and McCoy, R. E. 1983. Periwinkle wilt bacterium axenic culture pathogenicity and relationships to other Gram negative xylem inhabiting bacteria. Phytopathology 73:1510-1515.

12. De Lima, J. E. O., Miranda, V. S., Hartung, J. S., Brlansky, R. H., Coutinho, A., Roberto, S. R., and Carlos, E. F. 1998. Coffee leaf scorch bacterium: Axenic culture, pathogenicity, and comparison with Xylella fastidiosa of citrus. Plant Dis. 82:94-97.

13. French, W. J. 1982. Reciprocal transmission of plum leaf scald and phony disease of peach. Phytopathology 72:452-453.

14. Hartman, J. R., Jarlfors, U. E., Fountain, W. M., and Thomas, R. 1996. First report of bacterial leaf scorch caused by Xylella fastidiosa on sugar maple and sweetgum. Plant Dis. 80:1302.

15. Hendson, M., Purcell, A. H., Chen, D. Q. Smart, C., Guilhabert, M., and Kirkpatrick, B. 2001. Genetic diversity of Pierce's disease strains and other pathotypes of Xylella fastidiosa. Appl. Environ. Microbiol. 67:895-903.

16. Hernandez-Martinez, R., Costa, H. S., Dumenyo, C. K., and Cooksey, D. A. 2006. Differentiation of strains of Xylella fastidiosa infecting grape, almonds, and oleander using a multiprimer PCR assay. Plant Dis. In press.

17. Hill, B. L., and Purcell, A. H. 1995. Multiplication and movement of Xylella fastidiosa within grapevine and four other plants. Phytopathology 85:1368-1372.

18. Huang, Q., and Sherald, J. 2004. Isolation and phylogenetic analysis of Xylella fastidiosa from its invasive alternative host, porcelain berry. Curr. Microbiol. 48:73-76.

19. Kostka, S. J., Sherald, J. L., Hearon, S. S., and Rissler, J. F. 1981. Cultivation of the elm leaf scorch-associated bacterium (ESB). (Abstr.) Phytopathology 71:768.

20. Kostka, S. J., Sherald, J. L., and Tattar, T. A. 1982. Isolation of bacteria from three elm species and mulberry exhibiting leaf scorch (Abstr.) Phytopathology 72:936.

21. Kostka, S. J., Tattar, T. A., Sherald, J. L., and 
Hurtt, S. S. 1986. Mulberry leaf scorch new disease caused by a fastidious xyleminhabiting bacterium. Plant Dis. 70:690-693.

22. Li, W.-B., Zhou, C.-H., Pria, W. D., Jr., Teixeira, D. C., Miranda, V. S., Pereira, E. O., Ayres, A. J., He, C.-X., Costa, P. I., and Hartung, J. S. 2002. Citrus and coffee strains of Xylella fastidiosa induce Pierce's disease in grapevine. Plant Dis. 86:1206-1210.

23. Minsavage, G. V., Thompson, C. M., Hopkins, D. L., Leite, R. M. V. B. C., and Stall, R. E. 1994. Development of a polymerase chain reaction protocol for detection of Xylella fastidiosa in plant tissue. Phytopathology 84:456461.

24. Mircetich, S. M., Lowe, S. K., Moller, W. J., and Nyland, G. 1976. Etiology of almond leaf scorch disease and transmission of the causal agent. Phytopathology 66:17-24.

25. Page, R. D. M. 1996. TREEVIEW: An application to display phylogenetic trees on personal computers. Comput. Appl. Biosci. 12:357-358.

26. Pooler, M., and Hartung, J. S. 1995. Genetic relationship among strains of Xylella fastidiosa based on RAPD-PCR data. Curr. Microbiol. 31:134-137.

27. Purcell, A. H., Finlay, A. H., and McLean, D. L. 1979. Pierce's disease bacterium mechanism of transmission by leafhopper vectors. Science 206:839-841.

28. Purcell, A. H., Saunders, S. R., Hendson, M., Grebus, M. E., and Henry, M. J. 1999. Causal role of Xylella fastidiosa in oleander leaf scorch disease. Phytopathology 89:53-58.

29. Raju, B. C., Wells, J. M., Nyland, G., Brlansky, R. H., and Lowe, S. K. 1982. Plum leaf scald isolation culture and pathogenicity of the causal agent. Phytopathology 72:1460-1466.

30. Scally, M., Schuenzel, E. L., Stouthamer, R., and Nunney, L. 2005. Multilocus sequence type system for the plant pathogen Xylella fastidiosa and relative contributions of recombination and point mutation to clonal diversity. Appl. Environ. Microbiol. 71:8491-8499.

31. Schaad, N. W., Postnikova, E., Lacy, G., Fatmi, M. B., and Chang, C.-J. 2004. Xylella fastidiosa subspecies: X. fastidiosa subsp. fastidiosa, subsp. multiplex subsp. nov., and $X$. fastidiosa subsp. pauca. Syst. Appl. Microbiol. 27:290-300.

32. Schuenzel, E. L., Scally, M., Stouthammer, R., and Nunney, L. 2005. A multigene phylogenetic study of clonal diversity and divergence in North American strains of the plant pathogen Xylella fastidiosa. Appl. Environ. Microbiol. 71:3832-3839.

33. Sherald, J. L. 1993. Pathogenicity of Xylella fastidiosa in American elm and failure of reciprocal transmission between strains from elm and sycamore. Plant Dis. 77:190-193.

34. Sherald, J. L., Hearon, S. S., Kostra, S. J., and Morgan, D. L. 1983. Sycamore leaf scorch culture and pathogenicity of fastidious xylem limited bacteria from scorch affected trees. Plant Dis. 67:849-852.

35. Sherald, J. L., and Kostka, S. J. 1992. Bacterial leaf scorch of landscape trees caused by $X y$ - lella fastidiosa. J. Arboric. 18:57-63.

36. Sorensen, J. T., and Gill, R. J. 1996. A range extension of Homalodisca coagulata (Say) (hemiptera, clypeorrhyncha, cicadellidae) to Southern California. Pan-Pac. Entomol. 72:160-161.

37. Swofford, D. L. 2002. Phylogenetic Analysis Using Parsimony (and other Methods). Sinauer Associates, Sunderland, MA.

38. Thompson, J. D., Gibson, T. J., Plewniak, F., Jeanmougin, F., and Higgins, D. G. 1997. The CLUSTAL $X$ windows interface: Flexible strategies for multiple sequence alignment aided by quality analysis tools. Nucleic Acids Res. 25:4876-4882

39. Turner, W. P., and Herschel, N. 1959. Life histories and behavior of five insect vectors of phony peach disease. U.S. Dep. Agric. Tech. Bull. 1188.

40. Wells, J. M., Raju, B. C., Hung, H. Y., Weisburg, W. G., Mandelco-Paul, L., and Brenner, D. J. 1987. Xylella fastidiosa new-genus newspecies Gram-negative xylem-limited fastidious plant bacteria related to Xanthomonas-spp. Int. J. Syst. Bacteriol. 37:136-143.

41. Wells, J. M., Raju, B. C., and Nyland, G. 1983. Isolation culture and pathogenicity of the bacterium causing phony disease of peach Prunus persica. Phytopathology 73:859-862.

42. Wong, F., Cooksey, D. A., and Costa, H. 2005 Documentation and characterization of Xylella fastidiosa strains in landscape hosts. Proc. Pierce's Dis. Res. Sympos. December 5-7, San Diego, CA 